\title{
Construction and research of Thermal Engineering key specialty of Application - Oriented Talents Cultivation
}

\author{
LI Jiu-ru \\ Harbin University of Science and Technology \\ HUST \\ Harbin China \\ e-mail: hrblijiuru@sina.com
}

\author{
MENG Ling-kun \\ Harbin University of Science and Technology \\ HUST \\ Harbin China \\ e-mail: menglingkun258@126.com
}

\begin{abstract}
Thermal Engineering specialty of Harbin University of Science and Technology, in the process of construction of key specialty, , formed a thick essential, wide platform and high quality with construction system is conducive to optimizing the structure of specialty disciplines, deepen the reform of promoting the teaching and research and teaching, strengthen the construction of specialty content. Improving the quality of personnel training, specialty competence, to meet the needs of the Economic and Social Development ; by updating the concept of education, strengthen the construction of teaching staff, strengthening the construction of teaching conditions, reform of Practice Teaching Link, the reform of teaching contents and teaching methods and means ; strong impetus to the application - oriented talents cultivation.
\end{abstract}

Keywords-Application-Oriented Talents; Thermal Engineering; key specialty; specialty competence

\section{THE CONSTRUCTION OF CURRICULUM SYSTEM.}

In 2010,The revision to develop application - oriented talents as a starting point, larger adjustments to the curriculum system, and thick, wide and high quality taking into account the basis, the implementation of adaptive thermal engineering talents training model of diversified education reform and measures to increase the number of doors applied technology courses, updating and expansion of specialized courses and specialty courses[1], additional computer practice, skills training, awareness training practice, focusing on the students' ability of engineering practice and cultivation of innovative ability[2]. In view of the northeast old industrial base of talent demand situation to continue, " setting standards " research personnel training, focusing on the training of students' comprehensive quality and ability of engineering practice, allowing students to work to get into the role.

A. Public courses-focus on the organic combination of natural science education and social science education

For students the necessary knowledge and infrastructure, attention to the cultivation of students' basic quality, focused on the Sustainable Development of the students and the groundwork for students to continue learning so that students receive more generous public knowledge of the underlying disciplines, specialty discipline.
B. Subject courses of basic courses. specialty platformbroaden specialty-caliber, training application-oriented talents [3]

Subject based curriculum covers Engineering Graphics, Elect ric Engineering Theory,Engineering Mechanics,Mecha nical Design Basis,Material Molding Tech. To implement broad - range education, the establishment of a thermal energy pl atforms curriculum Group, will be a common basis of the spe cialty direction included in the Platform. Inclu- ding: Engin eering Thermodynamics,Engineering Fluid Me-chanics,Ther mal Transfer Theory,Power Mechanical Engi- neering Basis, Thermal Engineering and Power Testing、 Energy Saving an d Environmental Conservation and Manufacturing Technolo gy of Power Machines etc.

Specialty platform classes are listed in TABLE1. TABLE1 Specialty platform Schedule.

\begin{tabular}{|c|l|c|c|c|c|}
\hline \multicolumn{1}{|c|}{ Courses } & \multicolumn{3}{|c|}{ Hours Distribution } \\
\hline \multirow{5}{*}{ Major } & \multicolumn{1}{|c|}{ Course Names } & $\begin{array}{c}\text { Tota } \\
\text { hrs }\end{array}$ & $\begin{array}{c}\text { Lect } \\
\text { hrs }\end{array}$ & $\begin{array}{c}\text { Lab } \\
\text { hrs }\end{array}$ & $\begin{array}{c}\text { Com } \\
\text { prac }\end{array}$ \\
\cline { 2 - 7 } & $\begin{array}{l}\text { Power Mechanical } \\
\text { Engineering Basis }\end{array}$ & 44 & 44 & & \\
\cline { 2 - 7 } & $\begin{array}{l}\text { Intensity Analysis of } \\
\text { Pressure Containers }\end{array}$ & 46 & 46 & & \\
\cline { 2 - 7 } & $\begin{array}{l}\text { Thermal Engineering } \\
\text { and Power Testing }\end{array}$ & 46 & 44 & 2 & \\
\cline { 2 - 7 } & $\begin{array}{l}\text { Energy Saving and } \\
\text { Environmental } \\
\text { Conservation }\end{array}$ & 46 & 46 & & \\
\cline { 2 - 7 } & $\begin{array}{l}\text { Manufacturing } \\
\text { Technology of Power } \\
\text { Machines }\end{array}$ & 48 & 48 & & \\
\hline
\end{tabular}

C. Specialty program-focus on engineering practice and strengthen the design and practical abilities

This specialty with two specialty of thermal engineering and Refrigeration and Air Conditioning Engineering, specialty courses are divided into 2 levels of specialty direction of compulsory and elective courses. Specialty direction for the backbone of specialty courses required course, there are theoretical, experimental, curriculum design, as well as the contact frontier of students' expertise, and no 
longer by the specialty direction of specialty elective course course, encourages students to cross to take.

Specialty programs are listed in TABLE2

TABLE2 Specialty programs Schedule.

\begin{tabular}{|c|c|c|c|c|c|c|}
\hline \multicolumn{3}{|r|}{ Courses } & \multicolumn{4}{|c|}{$\begin{array}{c}\text { Hours } \\
\text { Distribution }\end{array}$} \\
\hline Cla & $\mathrm{C} / \mathrm{E}$ & Course Names & $\begin{array}{c}\text { Tota } \\
\text { hrs }\end{array}$ & $\begin{array}{c}\text { Lect } \\
\text { hrs }\end{array}$ & $\begin{array}{c}\text { Lab } \\
\text { hrs }\end{array}$ & $\begin{array}{l}\text { Com } \\
\text { prac }\end{array}$ \\
\hline \multirow{12}{*}{ 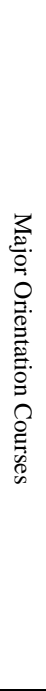 } & \multirow{6}{*}{ 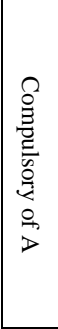 } & $\begin{array}{c}\text { Combustion Theory And } \\
\text { Equipment }\end{array}$ & 54 & 50 & 4 & \\
\hline & & Principles of Boilers & 70 & 68 & 2 & \\
\hline & & Power Plant & 36 & 36 & & \\
\hline & & Heat Supply Engineering & 48 & 44 & 4 & \\
\hline & & $\begin{array}{l}\text { Automatic Control of } \\
\text { Thermal Equipment }\end{array}$ & 38 & 36 & & 2 \\
\hline & & $\begin{array}{c}\text { Sub-total of } \\
\text { Compul.Orientation A }\end{array}$ & 246 & 234 & 10 & 2 \\
\hline & \multirow{6}{*}{ 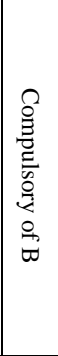 } & $\begin{array}{c}\text { Refrigeration Principles and } \\
\text { Tech. }\end{array}$ & 62 & 58 & 4 & \\
\hline & & $\begin{array}{l}\text { Refrigeration and Air- } \\
\text { conditioners }\end{array}$ & 44 & 44 & & \\
\hline & & Industrial Ventilation & 30 & 28 & 2 & \\
\hline & & Air Conditioning & 56 & 52 & 4 & \\
\hline & & $\begin{array}{l}\text { Automation of Refrigeration } \\
\text { Devices }\end{array}$ & 54 & 52 & & 2 \\
\hline & & $\begin{array}{c}\text { Sub-total of } \\
\text { Compul.Orientation B }\end{array}$ & 246 & 234 & 10 & 2 \\
\hline
\end{tabular}

\section{THE CONSTRUCTION OF TEACHERS}

Specialty regards retaining talents and attracting talents as a primary task of the major construction work, introducing than 3 people in recent years, PHD candidate in 1 people. To provide excellent working conditions and policies for young doctor, from the college leaders to each of the specialty teachers are very concerned about, caring and training of young teachers, therefore, absorb and retain the most highly educated young teachers, the teachers become the backbone of the specialty, so as to achieve stability, improving the education level of teaching staff, the purpose of improving the college structure.To promote the updating of teachers to further improve their comprehensive quality, we have also taken the following measuresEase of Use.

A. Encourage young teachers study for a doctorate, reduce the workload of their teaching.

B. Promote the establishment of the Institute and the research team $s$.

C. Strong support for the academic and specialty disciplines related activities, such as supporting the publication of textbooks and teachers college ; schools pay teachers in teaching and academic conferences or meetings ; the incumbents such as study abroad or internally oriented culture [4].

In 2010 Dr. subject teachers (and PhD) share reached $50 \%$, to ensure that the specialty qualifications of, and laid the foundation for a high level of research and teaching. In addition, our specialty attention, talent echelon construction of age, the title of reasonable structure. Currently we have 12 teachers in specialty, including professor 6, associate Professor or senior engineer 4 and lecturer 2. Our specialty teachers between the ages of 28-52, better combination of young and middle-aged, old teacher offered to help in scientific research and teaching with young teachers, promoting the growth of young teachers. Our expert specialty and technical seminars carried out about 5 times a year, the teacher talks, also appropriate to invite domestic development trends of relevant experts say the specialty front, broaden their knowledge.

We are specialized in teaching practice of long-term, emphasis on ethics, and style building, on teachers' moral cultivation and teaching of all aspects of work set specific requirements, so that all the teachers recognized his shoulder the responsibility of imparting knowledge and educating people, forming a higher quality teachers, and some meticulous, coaching, teaching and education typical strictly[5]. Our specialty each year to the new specifications for teaching and teacher education, specialty teachers' teaching style good of the whole, of the Steering Group have praised many times, over the years, there has never been any teaching accidents and errors.Taught Shi Kuang rate of $0 \%$, course completion rate of $100 \%$.

\section{CONSTRUCTION AND EXPERIMENTAL TEACHING REFORM OF EXPERIMENT TEACHING PLATFORM}

Engineering Application of practical ability cultivation of talents in culture is undoubtedly very important We have always attached great importance to the construction of experiment teaching for the major sectors, in the case of class tensions, has continued to increase the proportion of practice. At the same time in the construction and experimental teaching reform of experiment teaching platform, and take effective measures to ensure the level of experimental teaching to improve students' practical ability and proficiency[6].

Our specialty offers a total of 17 basic experiment, the experiment out of the rate of 100 . Open to students of laboratory rate of 90 per cent, number of students who participate in the open experiment for 40 . There are currently 8 experiment course, which includes comprehensive course 6 , designing experiments, and to cultivate students' innovative ability, combined with the teachers' scientific research projects, out of the 5 innovation and open experiment, the subject published on the Internet, students can a wide range of choices, greatly improves the students' creativity and practical ability[7].My specialty and research in construction at the same time.

\section{A. The construction of a high level of experimental teaching platform [8]}

Because of tight money, combined with high-end specialty equipment is expensive, difficulties in the construction of specialized laboratory construction for a time as a specialty. To this end, the construction of the major breakthroughs in general, proposed a joint laboratory 
construction and development, for I use ' laboratory construction of a new concept. To this end, the construction of the major breakthroughs in general, make' Joint Laboratory Construction and Development, for our use' laboratory construction of a new concept.

\section{B. Development of integrated experiment system}

In construction of key specialty, in addition to conventional construction of laboratory, with the major advantages of scientific research, focus on building integrated, research - oriented experiment teaching platform, development of appropriate high level Experiments on cultivating students' ability of system design system[6].

\section{Experiment Teaching Reform and experimental truly effective means for the development of learning new knowledge and practical abilities.}

Verify the means of experiments should not be only theoretical knowledge, but should be acquiring new knowledge, effective way to improve the practical ability. Under the guidance of the thought, to take full advantage of this resource, issued a more comprehensive experimental projects, particularly innovation, design experiment course of a proportion of the total course of the experiment, experimental significantly improve the content and effect[4].

\section{TEACHIng Reform And Management.}

\section{A. The teacher has always been a meticulous said, in} teaching, focus on teaching and education, study on the method of teaching theory with practice and education, practical training of students with strong ability to work.

Specialty in the new period is based on training compound, application of high - tech personnel with the objective of developing multi-faceted reform. Curriculum construction is the basic approach of training goals, specialty must be fully reflected in the curriculum construction. Emphasis on " Thick base, wide, high quality ", strengthening the infiltration of Arts and Sciences, the combination of science and technology[4]. Active Network Course Construction of excellent courses, excellent course and, on the construction of each course according to the requirements of key specialty, basic course content has a strong focus on specialized course, effectively increase the proportion of Practice Teaching arrangements, etc.

\section{B. Strengthening the construction of teaching materials.}

The quality of teaching material directly reflects the level of development of higher education and scientific research, but also directly affects the quality of undergraduate education. improve the teaching effect, heat engineering focused on undergraduate major specialty courses use more than the provincial excellent teaching materials, " 2 l century —oriented curriculum materials ", " eleventh five-year-plan ", " twelfth five-year-plan " recommended by the Steering Committee of the national educational materials and textbooks. And encourage higher levels of teaching experience, academic teacher compilation and publication of teaching materials with specialty features.
C. At present, my specialty education in the Teaching Reform in the run-up to 21st century, based on talents demand, strengthen the training in conjunction with industry, we take the initiative to form features [6].

The specialty teaching rule-based, there are legal basis, establish a stable teaching order, attaches great importance to the construction of teaching basic file and the rules and regulations.Summary of the calendar years teaching, curriculum, teaching, teacher's personal Teaching of Graduation Design In summary, check summing up the hunt teaching documents and materials, such as good, fully intact, the graduation project of papers and archives complete.

The macro-management for specialtys to enhance and improve the quality of teaching, increase the intensity of college teaching evaluation and inspection work[4]. Introduction of the colleges, the department and the teachers of the lecture system, after three years of continuous exploration and practice, a specialty leadership, expert groups, teachers and students to assess the main body of teaching supervision, to specialty teaching quality of teaching, teachers, students learn status for the assessment of specialty teaching evaluation system has basically taken shape.Implementing Department, teacher of the class system, after three years of continuous exploration and practice, a specialty leadership, expert groups, teachers and students to assess the main body of teaching supervision, to specialty teaching quality of teaching, teachers, students learn status for the assessment of specialty teaching evaluation system has basically taken shape. Improve teaching effectiveness, and to ensure the quality of personnel training, specialty in Graduate Project Selection and management take as early as the next topic, a large number of research projects chosen content, Teaching Joint Steering measures and methods to improve the comprehensive training effect, strengthening innovation andactual ability in teaching management and long-term adhere to "observe the incentive," hospital based leadership lectures at any monitoring "the way of effective teaching quality monitoring.

\section{THE EFFECTIVENESS OF MAJOR CONSTRUCTION AND EFFECT OF RADIATION}

This specialty to fit the width, targeted and welcomed by the society in general, its graduates are to have a more solid basic knowledge of hard working spirit, said. According to the school each year to the employer questionnaires and visits, as well as the understanding of the College to employers, employers are good things about the quality of our graduates, especially in our college graduates in the ideological and moral cultivation, basic knowledge, practical work, solidarity and cooperation to a higher evaluation, employers in our college graduates are welcome. The survey showed that increased level of graduates of teachers, serious examination of the performance appraisal, very pleased with the significant improvement in the classroom, greater on the experimental teaching for school equipment, books, the hardware improvement initiatives such as the gym was pleased with each passing day is attached to the alma mater of, for high school teaching job evaluation. 


\section{CONCLUSIONS}

Inter-university competition, the features of a large extent, competition, only attach importance to and strengthen the construction of key specialty in order to enhance the core competitiveness of the school. Our thermal engineering focus on specialty basis according to the School of Specialty and conditions, by teaching basic conditions for construction of the building, the construction of teaching staff, teaching materials, experimental course system construction of platform - building, research and practice, successfully declared a provincial excellent courses and two schools quality courses, successful batch of Heilongjiang Provincial Key specialty, have explored with Harbin University of Science and technology characteristic of heat engineering talents training mode and training programmes, basis for the development of thick, wide and high quality integrated contribute to the high quality talents.

\section{REFERENCES}

[1] Hou Li-song. Specialty Construction of Colleges and Universities, General Process[J]. Liaoning Education Research, Dec. 2005

[2] Zhang Jing-gang, Zhang Gui-ying, Research on construction of safety engineering characteristic specialty, JOURNAL OF SAFETY SCIENCE AND TECHNOLOGY, VOL. 7 No. 2, Feb. 2011.

[3] Cheng Jie, Fang Zheng-ping, Yan Hong-qiang, Practising and Reflect on the Construction of Polymer Materials and Engineering Specialty of Independent Institute , CHINESE POLYMER BULLETIN, Feb. 2011.

[4] Zhu Zhi-wei Policy research and practice of strengthening the construction of key specialty, Heilongjiang Higher Education Research, Jul.2012.

[5] Cai Boliang,The Problems in the Development of Economic Management Specialties at Teaching-Intensive Universities and the Solutions, Academic Exploration, Jul.2012.

[6] Wang Li-xin,Wang Ming-yan,Kang Ling, Engineering Electrical Engineering Construction and practice of cultivating innovative talents, CHINA UNIVERSITY TEACHING, May. 2012.

[7] Gao Bing-kun,Wang Xiu-fang, Talent internationalization and modernization of the information - oriented " 631 " model of fostering, Chinese Out of School Education, Aug.2009.

[8] Sun Xu-dong,Li Cheng-gang, Engineering Undergraduate research on training mode of creative talents- The United States rose-hulman Case Institute of Technology III, Higher Engineering Education and Research, Mar.2007. 